\title{
管状試験片によるクリープ破断試験についで
}

\author{
池島 俊 雄** 丸岡 秀 俊***
}

\section{On a Creep Rupture Test Applied to the Tubular Specimen}

\author{
by \\ Toshio Ikejima and Hidetoshi Maruoka \\ (Central Research Laboratories, Sumitomo Metal Industries Co., Ltd.)
}

Many high temperature alloys are used in tubular forms, but most of creep strength or creeprupture strength data for these materials are based on simple tension bar specimens. The hightemperature strength data based on bar specimens can't eliminate many of discrepancies between test of specimens and actual service. Many of investigators have developed the method closely simulated actual service condition. This method is the creep-rupture test adopted for a tubular specimen under internal steam pressure and at a controlled temperature. The author compared the creep-rupture characteristics of tubular and bar specimens for rolled material and welded joint. The following results were obtained:

(1) Agreement between the data of tubular and bar specimens of $18 \mathrm{Cr}-8 \mathrm{Ni} \cdot \mathrm{Ti}$ steel is good when the equivalent stress in tube wall is calculated on the formula which developed in ASME.

(2) In case that the strength of weld metal is stronger or indicates a similar degree of strength as compared with base metal, the creep-rupture strength of $18 \mathrm{Cr}-8 \mathrm{Ni} \cdot \mathrm{Ti}$ welded joint indicates the similar strength in comparison with base metal.

(3) In case that the strength is weaker than base metal, this $18 \mathrm{Cr}-8 \mathrm{Ni} \cdot \mathrm{Ti}$ welded joint decreases in high-temperature strength. But the degree of strength-lowering in the test applied to the bar specimen is more remarkable than that in the case applied to the tubular specimen.

(4) The creep-rupture strength of dissimilar joint between $18 \mathrm{Cr}-8 \mathrm{Ni}$. Ti steel and $21 / 4 \mathrm{Cr}$ $1 \mathrm{Mo}$ steel is lower than the strength of $2 \frac{1}{4} \mathrm{Cr}-1$ Mo steel. But, the degree of strength-lowering is more remarkable in the case of the bar specimen than in the case of the tubular specimen.

(Received Nov. 30, 1961)

\section{1. 緒}

溶接継手の高温強度の研究を行なう場合には, 継手 の応力状態を充分考慮しておくことが必要である。一 般に最も広く用いられているクリープ破断試験は, 丸 棒試験片を用いる単純な引張試験である。溶接継手の クリープ破断試験にこのような丸棒試験片を用いるこ とは，母材と溶接金属との境界面にほぼ直角方向の一 軸引張応力が加わる状態での試験ということになる. ところが鋼管の溶接継手では，内压により円周方向， 軸方向および半径方向の三軸応力を受け，その最大主 応力は円周方向の引張応力であって，母材と溶接金属 との境界面にほぼ平行である。

したがって，鋼管の溶接継手の高温強度を研究する 際に，丸棒試験片を用いたクリープ破断試験を実施す

\footnotetext{
* 原稿受付 昭和 36 年 11 月 30 日, 当協会第 4 回高温強度 シンポシ ウムにて講演 (昭 36.9 )

** 正員 住友金属工業(株)中央技術研究所

**** 住友金属工業(株)中央技術研究所
}

昭和 37 年 3 月

和和年 3 月
ることは，溶接継手の使用条件と非常に巽なる状態で の試験となり，その結果を直ちに使用するには多くの 問題点が内蔵されているものと推察することができる。 このような点を解明するために，筆者らは圧延材およ び溶接継手について, 丸棒試験片之管状試験片とを用 いたクリープ破断試験の比較をするようにした．

管状試験片によるクリープ試験あるいはクリープ破 断試験はすでに Norton, Kooistra および Davisによ って研究が進められており，筆者らはこれらの報告を 参考にして試験装置の試作を行ない，実験を行なうよ うにした。

\section{2. $18 \mathrm{Cr}-8 \mathrm{Ni} \cdot \mathrm{Ti}$ 鋼のクリープ破断試験}

溶接継手の比較に先だち，まず溶接金属を含まない 圧延材について管状試験片と丸棒試験片とによるクリ 一プ破断試験の比較をした。供試材料は Table 1 に 示す.

丸棒試験片は熱間圧延後冷間圧延を行なった板から 
平行部外径 $6 \mathrm{~mm} \phi \times$ 標点距離 $30 \mathrm{~mm}$ の試験片を作成 するようにした。溶体化処理は $1050^{\circ} \mathrm{C} \times 1 / 2 \mathrm{~h} \mathrm{W.Q.}$ である。管状試験片は外径 $50.8 \mathrm{~mm} \phi \times$ 肉厚 $7 \mathrm{~mm}$ の 冷間仕上鋼管を用い，丸棒試験片と同じ熱処理を行な った後, 内外面を削って外径 $47 \mathrm{~mm} \phi \times$ 肉厚 $3.5 \mathrm{~mm}$ $\times$ 平行部長 $350 \mathrm{~mm}$ の試験片を作成した. 試験片の形 状は Fig. 1 に示す.

管状試験片によるクリープ破断試験を行なう場合に は, 一軸引張応力の下におけるクリープ破断試験との 比較ができるように, 等価応力でもって試験結果の整 理をすることが必要である。鋼管の応力計算式は Buxton および Burrow が一般によく使用されている 計算式の紹介を行ない，さらに ASMEにて行なった 応力計算式の検討結果について報告している．筆者ら はその中で下記の計算式を用いて管状試験片によるク リープ破断試験結果を丸棒試験片のそれと比較するよ うにした。

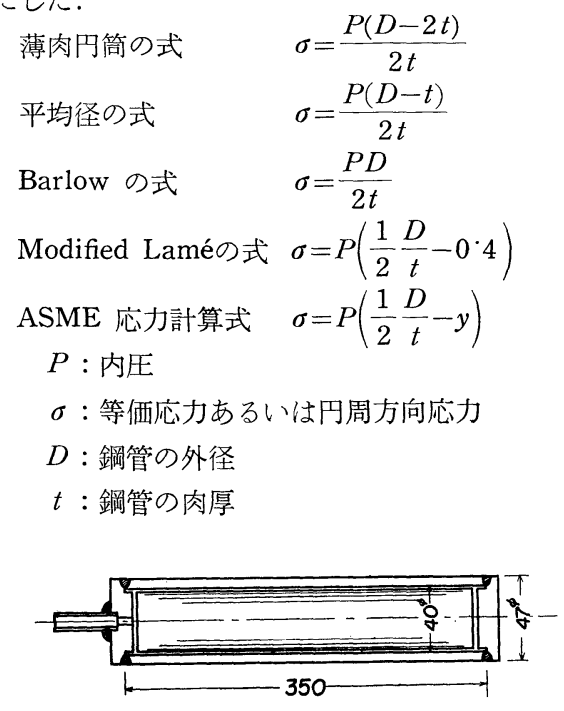

Fig. 1 Tubular specimen used
いま, 試験温度 $650^{\circ} \mathrm{C}$ の下で, 丸棒試験片と管状試 験片とによるクリープ破断試験結果を比較すると Fig. 2 のようになる。図からわかるように, 薄肉円筒の式 による計算応力を用いると，管状試験片は丸棒試験片 よりクリープ破断強度がやや低下する傾向にある.と ころが, Modified Lamé の式, 平均径の式および Barlow の式による応力を用いると，逆に丸棒試験片 より強度が高くなる傾向にある。一方, ASME 応力 計算式による応力を用いると, 丸棒試験片と全く同じ クリープ破断を示すことがわかった。

多軸応力状態における材料のクリープ破断について は従来から発表された報告が少なく，したがって，管 状試験片と丸棒試験片とによるクリープ破断強度の差 を理論的に推定することはできないうしかし，筆者の 実験結果あるいは Tucker らの報告によると,クリー プを考慮に入れた ASME 応力計算式を用いるならば， 比較的薄肉の管状試験片と丸棒試験片とによるクリー プ破断強度との間には実用上ほとんど差がないものと 考えてよい。

\section{3. $18 \mathrm{Cr}-8 \mathrm{Ni} \cdot \mathrm{Ti}$ 鋼溶接継手のクリープ破断試験}

次に，最近火力発電用ボイラに使用されるようにな った $18 \mathrm{Cr}-8 \mathrm{Ni} \cdot \mathrm{Ti}$ 鋼管の溶接継手について, 管状試 験片と丸棒試験片とによるクリープ破断試験を実施す

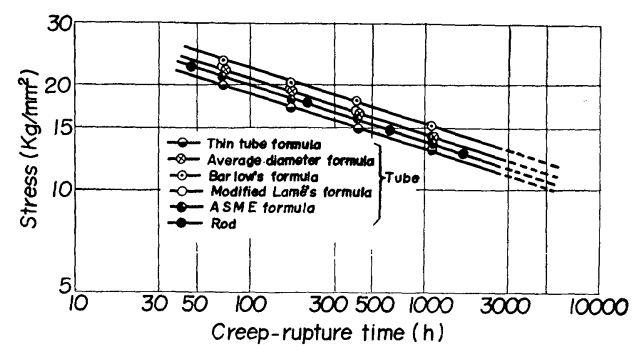

Fig. 2 Comparison of results of creep-rupture test using to tubular and bar specimen

Table 1 Chemical analysis of material tested

\begin{tabular}{c|c|c|c|c|c|c|c|c|c}
\hline Material & $\mathrm{C}$ & $\mathrm{Si}$ & $\mathrm{Mn}$ & $\mathrm{P}$ & $\mathrm{S}$ & $\mathrm{Cu}$ & $\mathrm{Cr}$ & $\mathrm{Ni}$ & $\mathrm{Ti}$ \\
\hline $18 \mathrm{Cr}-8 \mathrm{Ni} \cdot \mathrm{Ti}$ & 0.06 & 0.46 & 1.41 & 0.021 & 0.015 & 0.09 & 17.40 & 11.70 & 0.52 \\
\hline
\end{tabular}

Table 2 Chemical analysis of rolled material and deposit metals

\begin{tabular}{|c|c|c|c|c|c|c|c|c|c|c|c|c|}
\hline Material & $\mathrm{C}$ & $\mathrm{Si}$ & $\mathrm{Mn}$ & $\mathrm{P}$ & $\mathrm{S}$ & $\mathrm{Cu}$ & $\mathrm{Cr}$ & $\mathrm{Ni}$ & Mo & $\mathrm{Nb}$ & $\mathrm{Ti}$ & $\begin{array}{l}\text { Creep- } \\
\text { rupture } \\
\text { strength } \\
\text { at } 10^{4} \mathrm{~h} \\
\left(\mathrm{~kg} / \mathrm{mm}^{2}\right)\end{array}$ \\
\hline $\begin{array}{l}18 \mathrm{Cr}-8 \mathrm{Ni} \cdot \mathrm{Ti} \\
\text { rolled material }\end{array}$ & $0 \cdot 06$ & $0 \cdot 46$ & $1: 41$ & $0 \cdot 021$ & 0.015 & $0 \cdot 09$ & $17 \cdot 40$ & $11 \cdot 70$ & - & - & 0.52 & $9 \cdot 9$ \\
\hline 347-C deposit metal & 0.06 & 0.60 & $1 \cdot 53$ & $0 \cdot 013$ & 0.010 & $0 \cdot 15$ & $20 \cdot 60$ & $10 \cdot 22$ & - & 0.77 & - & $12 \cdot 0$ \\
\hline 16-8-2. A deposit metal & 0.08 & 0.24 & $1 \cdot 36$ & $0 \cdot 011$ & $0 \cdot 016$ & $0 \cdot 13$ & $14 \cdot 80$ & $7 \cdot 90$ & $1 \cdot 49$ & - & - & $7 \cdot 3$ \\
\hline $16-8-2 \cdot \mathrm{B}$ deposit metal & 0.08 & 0.23 & $1 \cdot 62$ & 0.013 & 0.015 & $0 \cdot 12$ & $15 \cdot 55$ & $9 \cdot 26$ & $1 \cdot 82$ & - & - & $10 \cdot 6$ \\
\hline
\end{tabular}


ることにした。供試鋼材および溶接棒の化学組成は Table 2 に示す. 参考のために，これらの供試材料を それぞれ単独にてクリープ破断試験を行ない求めた強 度も並記するようにした。

この表からわかるように, $18 \mathrm{Cr}-8 \mathrm{Ni} ・ \mathrm{Ti}$ 鋼の母材と 比較して, 各溶着金属のクリープ破断強度は347-Cの 場合は高く，16-8-2・Aの場合は低く，16-8-2・Bは同 程度ということになる。したがって，これらの溶接棒 による溶接継手のクリープ破断試験はそれぞれ溶接金 属が母材より強い場合, 弱い場合および同程度の場合 についての試験になる。

これらの溶接継手について前節と同じように，試験 温度 $650^{\circ} \mathrm{C}$ でのクリープ破断試験を実施した。管状試 験片は Fig. 1 と全く同じ寸法であって, 中央部に円 周方向の溶接継手をもっている. 丸棒試験片は供試鋼 管に似せた圧延および溶体化処理を行なった板の溶接 継手から採取するようにした。平行部直径 $6 \mathrm{~mm} \phi \times$

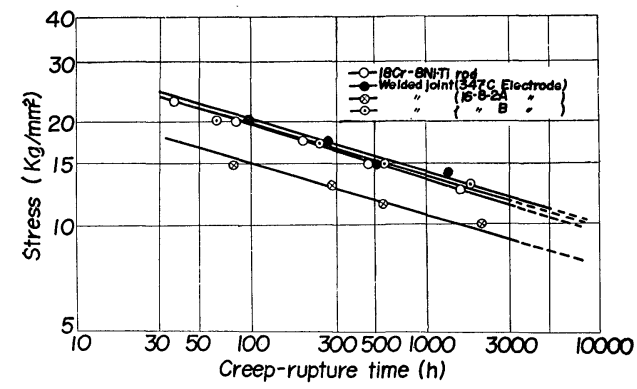

Fig. 3 Results of creep-rupture test of $18 \mathrm{Cr}$ $8 \mathrm{Ni} \cdot \mathrm{Ti}$ welded joint using to bar specimen

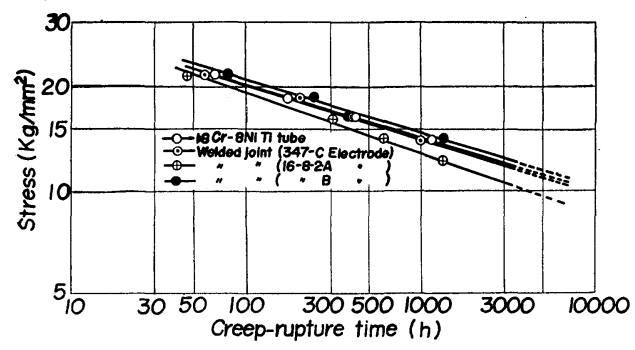

Fig. 4 Results of creep-rupture test of $18 \mathrm{Cr}$ $8 \mathrm{Ni} \cdot \mathrm{Ti}$ welded joint using to tubular specimen
標点距離 $70 \mathrm{~mm}$ の試験片である.いずれの試験片も 溶接のままで使用することにした。

試験結果は Fig. 3 およびFig. 4 に示すとおりであ る。図からわかるように，347-C および 16-8-2・B 溶 接棒による溶接継手では，管状試験片および丸棒試験 片ともに母材とほとんど変わらない強度を示すが, 16 -8-2・A 溶接棒による溶接継手では母材よりやや低い 強度を示す。しかし, 管状試験片と丸棒試験片とにお いて強度低下の割合が異なり，丸棒試験片のほうが顕 著な低下を示すことがわかった。この溶接継手のクリ 一プ破断強度は丸棒試験片では母材の 78～80\%であ るのに対し，管状試験片では 88～94\%である．この ような相違は溶接金属に加わる応力状態によって大き く影響されるものと考えられる，母材より弱い溶接金 属は試験中に両側の母材によってクリープ変形を拘束 される。したがって，丸棒試験片では，上下の母材の 拘束により融合線付近の溶接金属に半径方向の引張拘 束応力を生じているものと考えられる，一方，管状試 験片ではクリープ破断に主として寄与するのは円周方 向応力であり，この応力が溶接金属と母材との境界面 に平行に働いているので，溶接金属には左右の母材の 拘束のために円周方向の圧縮拘束応力を生じていると 考えられる。

このように生成した拘束応力の大きさおよび方向の 相違が，母材より弱い強度を示す溶接金属を持った溶 接継手において，管状試験片と丸棒試験片との間に認 められた強度差に大きく影響するものと考えられる。 また，溶接金属が母材より強い溶接継手あるいは同程 度の強度の溶接継手が母材と变わらない強度を示すこ とからわかるように，熱影響部が継手の強度に影響す ることはほとんどなく，継手強度は主として溶接金属 によって影響されることがわかった。

\section{4. $18 \mathrm{Cr}-8 \mathrm{Ni} \cdot \mathrm{Ti}$ 鋼と $21 / 4 \mathrm{Cr}-1 \mathrm{Mo}$ 鋼との 異材溶接継手のクリープ破断試験}

火力発電用ボイラに $18 \mathrm{Cr}-8 \mathrm{Ni}$ - Ti 鋼管が使用され るようになってきたために，21/4 Cr-1 Mo 鋼管との異 材溶接が問題になっているので，この節では異材溶接 継手のクリープ破断試験を実施する. Table 3 に供試 鋼材および溶接棒の化学組成を示す．この異材溶接継 手には，従来から用いられてきた D 347 溶接棒ととも

Table 3 Chemical analysis of rolled materials and deposit metals

\begin{tabular}{l|c|c|c|c|c|c|c|c|c|c|c|c|c|c|c}
\hline \multicolumn{1}{c|}{ Material } & $\mathrm{C}$ & $\mathrm{Si}$ & $\mathrm{Mn}$ & $\mathrm{P}$ & $\mathrm{S}$ & $\mathrm{Cu}$ & $\mathrm{Cr}$ & $\mathrm{Ni}$ & $\mathrm{Mo}$ & $\mathrm{Nb}$ & $\mathrm{Ti}$ \\
\hline 2 1/4 Cr-1Mo rolled material & 0.10 & 0.26 & 0.46 & 0.014 & 0.006 & 0.14 & 2.28 & - & 1.02 & - & - \\
18 Cr-8 Ni.Ti rolled material & 0.06 & 0.40 & 1.45 & 0.022 & 0.007 & 0.08 & 16.90 & 11.96 & - & - & 0.56 \\
D 347 deposit metal & 0.06 & 0.60 & 1.53 & 0.013 & 0.010 & 0.05 & 20.60 & 10.22 & - & 0.77 & - \\
Inconel deposit metal & 0.05 & 0.26 & 1.72 & 0.012 & 0.016 & 0.05 & 15.93 & 70.23 & 1.67 & 1.11 & - \\
\hline
\end{tabular}




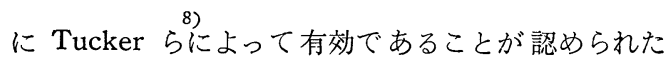
インコネル溶接棒を用いることにした.

管状試験片の形状は Fig. 5 に示す. $18 \mathrm{Cr}-8 \mathrm{Ni}$ ・Ti 鋼管による拘束をできるだけ少なくするために，溶接 金属の位置を中央部から移動させた. 丸棒試験片は板 の溶接継手より採取した。平行部直径 $10 \mathrm{~mm} \phi \times$ 標点 距離 $50 \mathrm{~mm}$ である.

$650^{\circ} \mathrm{C}$ にて行なった試験結果は Fig. 6, Fig. 7 に 示すとおりである. 図からわかるように, 丸棒試験片 によるクリープ破断試験では, 異材溶接継手は母材よ りかなり強度が低下している。D347 溶接棒による溶 接継手は $2 \frac{1}{4} \mathrm{Cr}-1 \mathrm{Mo}$ 鋼母材の $64 \%$ にまで低下し， インコネル溶接棒による溶接継手は $73 \%$ にまで低下 している。

一方，管状試験片によるクリープ破断試験では，短 時間側では溶接継手は母材と全く变わらない強度を示 すが，長時間側では母材よりやや低い強度を示す傾向 にある。しかし，丸棒試験片ほど顕著な低下を示さな いことがわかった。

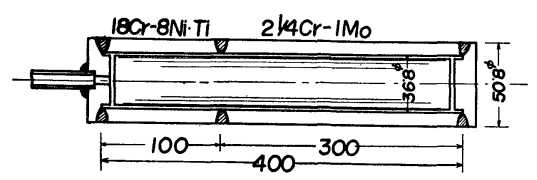

Fig. 5 Tubular specimen using to the dissimilar welded joint

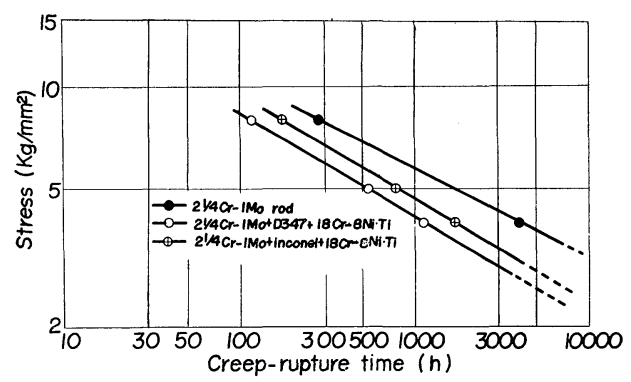

Fig. 6 Results of creep-rupture test of dissimilar welded joint using to bar specimen

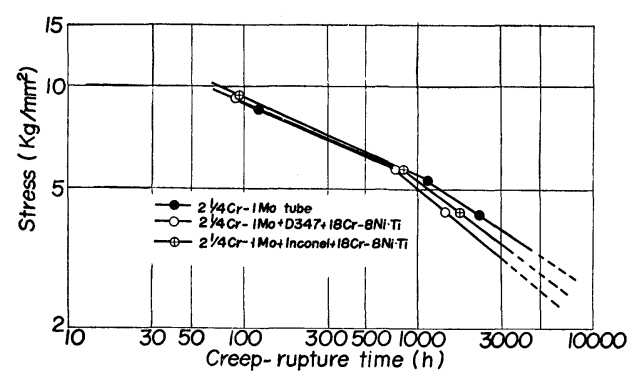

Fig. 7 Results of creep-rupture test of dissimilar welded joint using to tubular specimen
このように，異材溶接継手においても，管状試験片 と丸棒試験片とにより $2 \frac{1}{4} \mathrm{Cr}-1 \mathrm{Mo}$ 鋼母材からの強 度の低下がかなり異なっているが，この理由は次のよ うに考えられる。前節と同じように，異材溶接継手で も溶接金属近傍にて試験中に拘束応力を生ずることが 予測されるが，丸棒試験片では $2 \frac{1}{4} \mathrm{Cr}-1$ Mo 鋼とオ 一ステナイト溶接金属との耐酸化性の相違のために, 試験中に融合線に沿って切欠きを生じ，この切欠きが 試験応力にほぼ直角であるために, 試験片が切欠きを 生じた融合線に沿って破断することになる。しかも， 融合線付近の熱影響部は母材より低い強度を示すので， 溶接継手の強度が母材より低下するようになると考え られる。ただ，溶接金属によって強度に差を生ずるの は融合線に沼って $2 \frac{1}{4} \mathrm{Cr}-1$ Mo 鋼熱影響部に生成し た脱炭層の相違による。一方，管状試験片では，熱影 響部のクリープ变形は隣接する溶接金属によって拘束 されており，しかも融合線付近に生成した切欠さおよ び脱炭層に対して円周方向応力が平行に働くので，こ れらの効果が大きく作用することなく，21/4 Cr-1 Mo 鋼の母材原質部にて破断する。したがって，母材との 強度差をほとんど生じないものと判断しうる。

\section{5. 総括}

以上の試験結果を総括すると次のとおりである.

（1）溶接金属を含まない $18 \mathrm{Cr}-8 \mathrm{Ni} \cdot \mathrm{Ti}$ 鋼のクリ ープ破断試験結果により，管状試験片の試験結果を ASME 応力計算式による等価応力で整理すると, 丸 棒試験片とほとんど变わらない強度を示すことがわか った。

（2） $18 \mathrm{Cr}-8 \mathrm{Ni} ・ \mathrm{Ti}$ 鋼溶接継手では，溶接金属が 母材より強い場合および同程度の強度の場合は管状試 験片および丸棒試験片ともに母材と变わらない強度を 示す。一方，溶接金属が母材より弱い場合には母材よ り強度が低下するが，この強度低下は管状試験片では 丸棒試験片ほど顕著でないことがわかった。

(3) $18 \mathrm{Cr}-8 \mathrm{Ni} \cdot \mathrm{Ti}$ 鋼と $2 \frac{1}{4} \mathrm{Cr}-1 \mathrm{Mo}$ 鋼との異材 溶接継手の強度は, 丸棒試験片による試験では $21 / 4 \mathrm{Cr}$ -1 Mo 鋼母材よりかなり低下するが，管状試験片では ほとんど低下しないことがわかった。

（4）このような結果から, 圧延材のクリープ破断 強度は丸棒試験片の結果で充分であるが, 鋼管の溶接 継手のクリープ破断強度には管状試験片による結果を 用いるほうが妥当であると判断しうる.

\section{参 考 文 献}

1) F.H. Norton, Trans. ASME, 61, 239 (1939)

2) L.F. Kooistra et al., Trans. ASME, 74, 783 (1952)

3) E.A. Davis, Trans. ASME, 82, 453 (1960)

4) 丸岡, 住友金属, 13, 125 (1961)

5) W.J. Buxton et al., Trans. ASME, 73, 575 (1951)

6) W.R. Burrows et al., Trans. ASME, 76, 427 (1954)

7) J.T. Tucker et al., Trans. ASME, 82, 465 (1960)

8) J.T. Tucker et al., Weld. J., 35, 457-s (1956) 